\title{
Kajian Kelayakan Pengembangan Usaha Ternak Sapi Tebu di Kabupaten Majalengka
}

\section{The Feasibilty Study of Developing Integrated Beef Cattle, Sugar Cane Plantation and Sugar Processing Plant in Majalengka, West Java}

\author{
M.S. Harahap ${ }^{1}$ Firsoni $^{2}$ dan Yunilas ${ }^{3}$ \\ $\left.{ }^{1}\right)$ Badan Diklat Propinsi Sumatera Utara, \\ $\left.{ }^{2}\right)$ Badan Tenaga Nuklir Nasional \\ $\left.{ }^{3}\right)$ Fakultas Peternakan Universitas Sumatera Utara, Medan \\ E-Mail: syafril.harahap66@gmail.com \\ (Diterima:14 Desember 2013; Disetujui: 09 Februari 2014)
}

\begin{abstract}
ABSTRAK
Pengembangan usaha peternakan sapi di Indonesia perlu untuk meraih dua hal; (1) upaya memenuhi kebutuhan protein hewani dan (2) mengurangi impor daging. Karena investasi pengembangan cukup besar, perlu kajian kelayakan usaha integrasi ternak sapi di sekitar kebun tebu dan pabrik gula PG Jatitujuh Majalengka Propinsi Jawa Barat. Kegiatan ini bertujuan membangun sinergi peternakan sapi, perkebunan tebu dan pabrik gula. Pengambilan data dilakukan dengan metode survey dan wawancara. Analisis kelayakan usaha meliputi aspek pasar, teknis, keuangan serta aspek sosial dan ekonomi. Hasil analisis menyimpulkan bahwa investasi usaha pembibitan layak untuk dikerjakan dalam waktu 10 tahun dengan analisa sensitifitas IRR 13,97\%. Sedangkan usaha penggemukan layak dilakukan pada waktu 5 tahun dengan IRR 18,92\%.
\end{abstract}

Kata kunci : kelayakan investasi, sapi, tebu, pabrik gula, IRR

\section{ABSTRACT}

The development of beef cattle farm in Indonesia is necessitated for two reasons (1) providing people with required animal protein and reducing the number of meat import. Due to high cost of investment, it was necessary to find out an alternative study on the feasibility of integrated beef cattle farm with sugar cane plantation and sugar industry area at PG Jatitujuh, West Java. This research was conducted to establish the sinergy among beef cattle farm, sugar cane plantation and sugar industry. Survey and interview were used to collect primary datas. Scoping of the study include several aspects (market, technique, finance and socio-economics). The results showed that investment in the breeding business was feasible to implement for ten years on sensitivty analisys (IRR) at 13.97\%. Then beef cattle fattening business was feasible for 5 years by IRR level at $18.92 \%$.

Keywords : investment feasibility, beef cattle, sugar cane, sugar factory, IRR

\section{PENDAHULUAN}

Salah satu masalah yang amat penting bagi ketahanan suatu masyarakat atau bangsa adalah tersedianya bahan makanan bagi penduduknya. Bangsa yang mampu menyediakan bahan makanan bagi rakyatnya dengan cukup baik jumlah maupun kualitasnya akan mempunyai ketahanan nasional yang baik. Sebaliknya, bangsa yang tidak mampu menyediakan bahan makanan secara cukup akan mempunyai ketahanan nasional yang buruk. Ketergantungan pangan terhadap negara lain akan menguras devisa negara dan sekaligus akan menghancurkan sumber daya lokal di bidang pangan serta rentan terhadap embargo pangan. Salah satu bahan pangan yang sampai sekarang masih sangat rentan karena sebagian masih impor adalah daging sapi.

Import daging sapi dan bakalan dewasa ini terjadi secara besar-besaran. Hal ini terjadi dikarenakan populasi ternak potong terutama 
sapi mengalami penurunan yang cukup tajam dari tahun ke tahun. Diduga penyebab penurunan ini adalah menyusutnya populasi sapi potong dalam negeri dan pemotongan ternak betina produktif. Hal ini ditengarai dengan maraknya pemotongan sapi dalam beberapa tahun terakhir tanpa diimbangi upaya peningkatan populasi sapi secara berkelanjutan. Berdasarkan pernyataan BPS (2013) bahwa populasi sapi dan kerbau pada $1 \mathrm{Mei}$ 2013 mencapai 14,2 juta ekor atau mengalami penurunan yang cukup tajam bila dibandingkan dengan hasil pendataan Sapi Potong pada 2011 (14,82 juta ekor).

Upaya yang dilakukan pemerintah dalam mengatasi permasalahan impor daging dan bakalan salah satunya adalah pencanangan swasembada daging sapi. Untuk mendukung pencapaian target swasembada daging pada tahun 2014 dapat dilakukan dengan mengoptimalkan integrasi sawit ternak dan penggalakan pemeliharaan betina produktif, bahkan integrasi usaha perkebunan lainnya dengan ternak termasuk perkebunan tebu. Dengan demikian, pengembangan usaha ternak sapi sebagai penyedia daging menjadi sangat mendesak. Ini disebabkan sampai saat ini Indonesia untuk memenuhi konsumsi daging dalam negeri masih mengimpor sapi bakalan dari Australia. Untuk tahun 2011 Indonesia telah mengimpor 350.000 ekor sapi dari Australia, dan direncanakan pada tahun 2012 sebanyak 700.000 ton daging. Impor sapi dilakukan karena ketidakmampuan produksi daging dalam negeri dalam mensuplai konsumsi daging di dalam negeri yang semakin meningkat setiap tahun.

Di sisi lain dengan berkembangnya industri pertanian di Indonesia, khususnya di bidang perkebunan yang menghasilkan limbah yang dapat digunakan sebagai pakan ternak sapi, membuat usaha peternakan akan sangat menguntungkan bila diintegrasikan dengan usaha perkebunan tersebut. Untuk itu, salah satu program pemerintah yang telah dilaksanakan adalah program "Sa-Sa" (Sawit Sapi) yang merupakan program unggulan dari Badan Usaha Milik Negera (BUMN). Untuk tahun 2012 target program "Sa-Sa" adalah pemeliharaan sapi pada perkebunan sawit sebanyak 100.000 ekor, dan meningkat pada tahun 2013 direncanakan menjadi 200.000 ekor.

Salah satu Badan Usaha Milik Negara (BUMN) merespon kegiatan program tersebut dengan melakukan rencana untuk mengembangkan usaha peternakan sapi di beberapa holding company, khususnya perkebunan yang bergerak di komoditi tanaman kelapa sawit dan tanaman tebu PG. Jatitujuh di Kabupaten Majelengka berencana untuk melakukan usaha ternak sapi dengan memanfaatkan potensi limbah industri pertanian (pabrik gula) seperti bagase, molases dan lain-lain sebagai pendukung utama dalam penyediaan pakan ternak. Usaha peternakan ini juga direncanakan terintegrasi dengan usaha perkebunan, sehingga diharapkan dapat dihasilkan usaha peternakan yang efisien dan menguntungkan dengan adanya integrasi antara industri pertanian, perkebunan dan peternakan.

Berdasarkan hal tersebut diatas, maka dilakukan suatu pengkajian kelayakan usaha pemeliharaan sapi yang berintegrasi antara peternakan sapi dengan perkebunan tebu dengan menerapkan Manajemen Pola Kemitraan. Fokus kajian terdiri aspek teknis untuk aktivitas investasi, dan kelayakan usaha berdasarkan parameter investasi yang meliputi internal rate of return (IRR), net present value (NPV) benefit cost ratio (B/C ratio), dan Manajemen Pola Kemitraan.

\section{METODE}

\section{Lokasi penelitian}

Penelitian dilakukan di Perkebunan Tebu dan Pabrik Gula PG Jatitujuh, Kabupaten Majalengka Provinsi Jawa Barat, secara geografis terletak di bagian timur provinsi Jawa Barat diantara koordinat $108^{0}$ 12 " s/d $108^{0} 25$ " Bujur Timur, 60 36 "s/d $6^{0}$ 58" Lintang Utara dan $6^{0} 43$ "s/d $7^{0} \quad 03$ " Lintang Selatan. Topografinya, secara umum Kabupaten Majalengka terbagi menjadi 3 (tiga) bagian, yaitu daerah pegunungan dengan ketinggian 500 - $857 \mathrm{~m}$ di atas permukaan laut dengan luas $482,02 \mathrm{~km}^{2}$ atau $40,03 \%$ dari seluruh luas wilayah Kabupaten Majalengka ; 


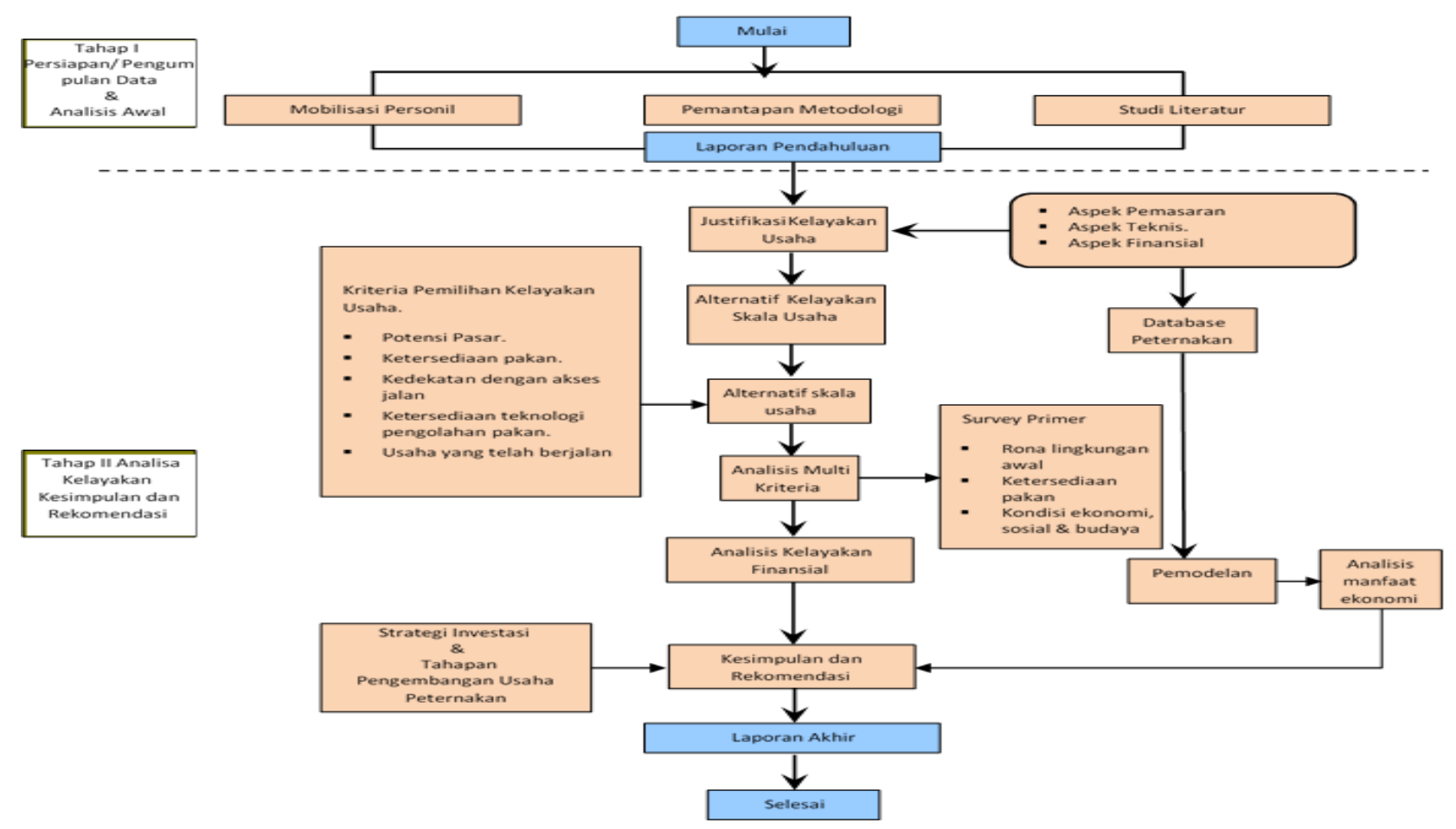

Gambar 1. Bagan alir kegiatan

bergelombang/berbukit dengan ketinggian 50$500 \mathrm{~m}$ diatas permukaan laut dengan luas $376,53 \mathrm{~km}^{2}$ atau $31,27 \%$ dari seluruh luas wilayah Kabupaten Majalengka; Dataran rendah dengan ketinggian 19-50 $\mathrm{m}$ diatas permukaan laut dengan luas $345,69 \mathrm{~km}^{2}$ atau $28,70 \%$ dari seluruh luas wilayah Kabupaten Majalengka. Pada umumnya Kabupaten Majalengka berada pada ketinggian 19-857 m diatas permukaan laut dengan suhu udara di Kabupaten Majalengka rata-rata berkisar antara $26,5^{\circ} \mathrm{C}$ sampai $28^{\circ} \mathrm{C}$. Suhu udara maksimum terjadi pada bulan April dan Oktober yaitu $33,1^{\circ} \mathrm{C}$, sedangkan suhu udara minimum terjadi pada bulan Juli dengan suhu sebesar $23^{\circ} \mathrm{C}$. Curah tertinggi terjadi pada bulan Maret yang mencapai $586 \mathrm{~mm}$ dengan jumlah hujan 22 hari, dan terendah pada bulan Juli yaitu $89 \mathrm{~mm}$ dengan jumlah hari hujan 17 hari.

\section{Metode Pengambilan Sampel dan Analisis Data}

Metode pengumpulan data dilakukan dengan 2 (dua) cara yaitu metode pengumpulan data sekunder dan metode pengumpulan data primer. Metode pengumpulan data sekunder dilakukan dengan mendatangi instansi terkait untuk memperoleh data-data yang berkaitan dengan usaha pengembangan peternakan dan kondisi peternakan, sosial budaya dan instansi-instansi lain yang dapat menyediakan data yang berkaitan dengan studi kelayakan ini. Metode pengumpulan data primer dilakukan dengan survey kondisi usaha peternakan yang sedang berjalan untuk selanjutnya yang akan dikembangkan, survey secara lebih rinci kondisi sarana dan prasarana seperti; kondisi lahan, kandang dan aspek lainnya dengan cara observasi lapang dan wawancara. Pembahasan meliputi beberapa aspek yaitu; aspek pemasaran; aspek teknis produksi; aspek keuangan; dan aspek sosial dan ekonomi.

\section{Proses Analisis Kelayakan}

Perbandingan biaya (cost) dan manfaat/ pengembalian (benefit/ revenue) merupakan basis dalam menentukan kelayakan ekonomi dan finansial dari Pengembangan Usaha Ternak Sapi Sawit di Sumatera Selatan dan Sapi Tebu di Kabupaten Majalengka. Proses analisis kelayakan dilakukan dengan 3 (tiga) tahap, yaitu : 
1. Tahap proses estimasi biaya ekonomi /finansial (biaya konstruksi, operasi dan pemeliharaan).

2. Melakukan estimasi pendapatan finansial dari Pengembangan Usaha Ternak Sapi Sawit di Sumatera Selatan dan Sapi Tebu di Kabupaten Majalengka.

3. Melakukan analisis dengan menggunakan metode IRR, NPV, BEP dan BCR.

\section{HASIL DAN PEMBAHASAN}

\section{Aspek Pasar dan Pemasaran}

Prospek usaha peternakan sapi di Indonesia masih sangat terbuka, hal ini disebabkan permintaan daging sapi dari tahun ke tahun terus meningkat. Peningkatan ini sejalan dengan peningkatan taraf hidup dan kesadaran akan kebutuhan gizi masyarakat. Selain itu dengan semakin bertambahnya jumlah penduduk berarti semakin bertambah pula konsumsi daging sapi yang dibutuhkan. Sebaliknya dari pihak peternak semakin kewalahan dalam menyuplai untuk memenuhi permintaan dari waktu ke waktu.

Kamar Dagang dan Industri (Kadin) mencatat, setiap tahun masyarakat Indonesia membutuhkan sekitar 350.000 sampai 400.000 ton daging sapi. Jumlah itu setara dengan sekitar 1,7-2 juta ekor sapi potong. Dari jumlah tersebut hingga saat ini Indonesia masih mengimpor sekitar $40 \%$ daging sapi. Pada tahun 2012 pemerintah merencanakan import daging sebanyak 85.000 ton dan sapi bakalan sebanyak 283.000 ekor.

Berdasarkan uraian di atas, dapat diketahui bahwa prospek peluang pasar daging sapi dari tahun ke tahun terus meningkat sejalan dengan peningkatan taraf hidup dan kesadaran akan kebutuhan gizi masyarakat, diimbangi dengan bertambahnya jumlah penduduk yang berarti semakin bertambah pula konsumsi daging sapi yang dibutuhkan.

Permintaan pasar terhadap daging sapi masih terus mengalami peningkatan, dan usaha ini potensi dikembangkan, karena usaha ternak penggemukan dan pembibitan sapi potong tidak sesulit dan seberat usaha ternak komoditas lainnya, seperti ternak sapi perah atau ayam petelur. Pemasaran sapi potong tidak perlu dilakukan setiap hari, karena penduduk Indonesia biasa mengkonsumsi daging sapi sebagai menu sehari-hari dan pada saat hari raya atau upacara adat permintaan sapi potong meningkat drastis. Dengan melihat kondisi tersebut, peluang pasar dan pemasaran usaha peternakan sapi potong masih terbuka luas.

Jalur pemasaran sapi potong dari peternak hingga ke pengepul dan pasar besar dapat dilihat pada Gambar 2.

\section{Aspek Teknis dan Produksi}

Aspek teknis merupakan aspek yang menilai suatu usaha dikatakan layak dilihat dari teknis operasional secara rutin dan teknologi yang akan digunakan sehingga dalam saat operasional tidak terjadi kesalahan fatal yang akan membuat biaya produksi semakin tinggi dan faktor-faktor lainnya yang akan membuat kerugian bagi perusahaan di masa yang akan datang (Umar, 2001). Lahan dan lokasi ternak sapi yang dimiliki oleh PG. Jatitujuh sudah memadai. Untuk memelihara ternak sapi dibutuhkan lahan kandang, kandang umumnya berupa bangunan permanen sederhana. Kandang yang dibangun harus bisa menunjang peternak, baik dari segi ekonomis maupun segi kemudahan dalam pelayanan. Dengan demikian diharapkan bahwa dengan adanya bangunan kandang ini sapi tidak berkeliaran di sembarang tempat dan kotorannya pun bisa dimanfaatkan seefisien mungkin.

Sapi jantan lebih cocok dijadikan sapi potong karena sapi jantan memiliki pertambahan berat daging harian yang lebih tinggi dibandingkan dengan sapi betina. Selain itu, ada peraturan yang melarang memotong ternak sapi betina yang masih produktif. Jenis sapi bakalan import biasanya didatangkan dari Australia dan Selandia baru. Jenis sapi yang didatangkan biasanya berasal dari jenis brahman cross atau australian comercial cross. Sapi ini memiliki berat dan umur yang seragam, serta pertambahan berat badan cukup tinggi yaitu $0,8-1,2 \mathrm{~kg} / \mathrm{hari}$. Berat awal sapi bakalan berkisar $250-350 \mathrm{~kg}$ dengan umur sapi 1-2 tahun. 


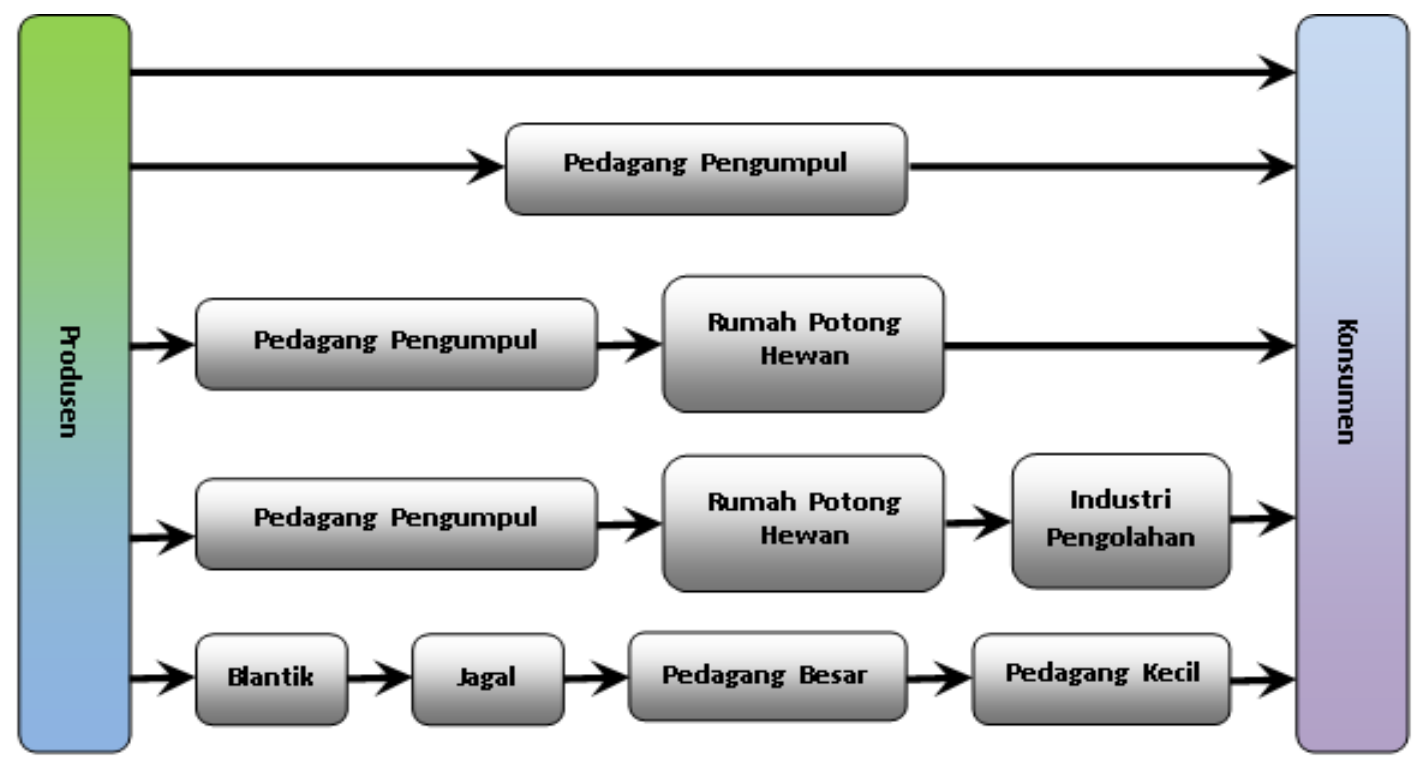

Gambar 2. Jalur pemasaran sapi potong

Bahan pakan yang digunakan oleh peternak sapi PG. Jatitujuh, terbagi atas dua macam yaitu pakan hijauan dan konsentrat. Pakan hijauan yang utamanya terdiri atas pucuk tebu, sogolan, kletekan, jerami padi dan dilengkapi oleh pakan peningkat nilai gizi dan daya cerna yaitu konsentrat. Kebutuhan pakan hijauan dipenuhi sendiri dengan memanfaatkan sumber pakan yang berasal dari sebagian yang dianggap limbah dari perkebunan seperti pucuk tebu. Hal itu meminimalkan biaya pakan karena peternak dapat mendapatkan pakan hijauan secara gratis.

Pakan untuk ternak sapi potong dapat berupa hijauan (pelepah sawit, pucuk tebu, sogolan dan kletekan) serta makanan tambahan (vitamin, mineral, dan urea). Pakan hijauan dapat dibagi menjadi 3 kategori, yaitu : hijauan segar, hijauan kering, silase. Pembuatan silase biasanya ditempatkan di kantong plastik tebal, gentong plastik, atau di dalam lubang tanah yang telah dialasi plastik. Lama proses silase tergantung jenis bahan. Namun, dalam waktu 2-3 minggu biasanya silase dapat di panen. Contoh silase yaitu silase pucuk tebu, sogolan, kletekan, silase jagung, silase rumput, dan silase jerami padi.

Pakan konsentrat adalah campuran bahan pakan (ransum) untuk ternak sapi. Bahan penyusun pakan konsentrat diantaranya adalah dedak padi, ampas singkong (onggok), ampas tahu, bungkil kelapa sawit, bungkil kedelai, dan bungkil kacang tanah.

Selain pemberian pakan hijauan dan konsentrat, agar pertumbuhan sapi bisa lebih cepat maka dapat diberikan pakan tambahan berupa suplemen seperti mikronutrien dan vitamin B kompleks. Selain untuk meningkatkan nafsu makan, pemberian suplemen juga ditujukan untuk memacu proses penyusunan protein di dalam pencernaan dan menjaga kesehatan. Contoh pakan tambahan diantaranya vitamin, mineral, urea, $\mathrm{CaCO}_{2}, \mathrm{Ca}_{3}$ $\left(\mathrm{PO}_{3}\right)_{2}$, dan garam dapur. Jumlah pakan tambahan yang diberikan adalah $1 \%$ dari total ransum yang diberikan kepada sapi.

Pakan untuk ternak sapi yang dipakai pada usaha peternakan di PT. Jati Tujuh, disusun berdasarkan kebutuhan ternak sapi, yang terdiri dari pakan untuk sapi penggemukan, pakan sapi bunting 0-7 bulan dan pakan sapi bunting 7 bulan hingga lahir. Hal ini disebabkan karena kebutuhan masing-masing sapi tersebut berbeda satu sama lain. Sedangkan bahan-bahan penyusun ransum pakan dengan komposisi tertentu yang disesuaikan dengan kebutuhan nutrisi sapi untuk PT. Jati Tujuh adalah pucuk tebu, sogolan, kletekan ditambah dengan bungkil kelapa, dedak halus, tetes (molasses), urea, mineral dan garam.

Pemeliharaan sapi potong yang dikembangkan PG. Jatitujuh adalah penggemukan 
dan pembibitan dengan cara dikandangkan, cara ini mengutamakan pemberian pakan berupa pucuk tebu, sogolan, kletekan, dan lain-lain. Sejak awal sapi digemukkan dari pembibitan sampai pemasaran, memperoleh pakan konsentrat secara penuh, sedangkan pakan berupa hijauan diberikan dalam jumlah terbatas.

Sapi potong dapat dipanen setelah 120 hari penggemukan dengan berat $+420 \mathrm{~kg}$. Penimbangan berat akhir di lakukan di lokasi perusahaan mitra atau di lokasi peternak sesuai perjanjian. Karena transportasi sapi bisa menganggu berat badan, maka apabila di timbang di lokasi mitra, lokasi peternakan harus tidak jauh dari lokasi perusahaan mitra (sekitar 1 jam perjalanan kendaraan). Sapi induk afkir dijual dengan berat rata-rata +400 $\mathrm{kg}$, sapi jantan umur 2 (dua) tahun dijual dengan berat rata-rata $+450 \mathrm{~kg}$ dan sapi betina umur 2 (dua) tahun dijual dengan berat ratarata $+400 \mathrm{~kg}$ dengan harga jual sapi $\mathrm{Rp}$ $32.000,-/ \mathrm{kg}$.

Pembibitan dimulai pada tahun ke 3 (2014), anak sapi hasil pembibitan dapat dijual setelah berumur 2 (dua) tahun dimulai pada Tahun 2016. Produksi sampingan yang diproduksi oleh peternakan sapi yaitu pupuk kandang. Setiap tahun menghasilkan kotoran sebanyak $\pm 1.000-16.000 \mathrm{~kg}$.

\section{Aspek Keuangan}

Biaya investasi diperlukan untuk memulai usaha penggemukan dan pembibitan sapi meliputi biaya pembuatan kandang, peralatan kandang, listrik dan lain-lain. Jumlah biaya investasi yang diperlukan untuk peternakan sapi PG. Jatitujuh sebesar Rp 45.624.986.106,- untuk pembibitan dan penggemukan serta Rp 43.123.586.106 untuk penggemukan.

Biaya operasional merupakan biaya yang diperlukan dalam usaha penggemukan dan pembibitan sapi serta usaha penggemukan sapi. Besarnya biaya operasional ini tergantung pada jumlah sapi yang akan di pelihara. Semakin banyak jumlah sapi yang akan dipelihara maka biaya operasional akan semakin tinggi. Oleh karena itu, biaya operasional umumnya merupakan biaya tidak tetap (vari- able cost) yang terdiri dari biaya pakan, tenaga kerja, bahan baku, pemeliharaan dan perlengkapan penunjang usaha. Biaya operasional peternakan sapi PG. Jatitujuh sebesar Rp 651.635.044.575,- untuk pembibitan dan penggemukan serta Rp 905.848.431.577,-

Produksi Sapi potong berasal dari sapi bakalan yang digemukan dengan waktu 120 hari (1 periode), setelah mencapai waktu yang ditentukan (120 hari) kemudian dijual kepada mitra usaha. Dalam satu tahun, peternak dapat menjual sapi sampai dengan 3 (tiga) kali per periode. Dalam satu kali panen untuk 1 (satu) ekor sapi diperoleh hasil produksi sebesar 400 sampai $450 \mathrm{~kg}$ dengan harga jual sebesar Rp $32.500,-/ \mathrm{kg}$ berat hidup atau sebesar Rp.13.000.000,- sampai Rp 14.625.000,- per periode, untuk sapi bibit peternak menjual anak sapi jantan dan anak sapi betina umur 2 (dua) tahun. Selain produksi berupa sapi dapat diperoleh produk ikutan berupa kotoran sapi sebanyak 1.000 sampai 16.000 ton per tahun dengan harga jual Rp 150 per $\mathrm{kg}$.

Dari arus kas di ketahui bahwa pada suku bunga $12 \%$ per tahun, usaha pembibitan dan penggemukan sapi mengalami kerugian pada tahun keempat dan kelima. Kerugian ini disebabkan pembelian induk sapi pada tahun ketiga dan pemberian pakan induk sapi bunting maupun sapi laktasi serta pakan anak sapi. Namun untuk usaha penggemukan sapi ini mampu membayar kewajiban pembiayaan dan menghasilkan keuntungan. Dengan demikian usaha pembibitan dan penggemukan sapi dalam kurun waktu lima tahun rencana belum layak dilaksanakan.

Pada analisa kelayakan dapat juga memakai beberapa indikator yang umum digunakan pada perhitungan konvensional, indikator tersebut meliputi IRR (Internal Rate of Return), NPV (Net Present Value), Net B/C ratio (Net Benefit-Cost ratio), BEP (Break Event Point) dan PP (Pay-back Period).

Berdasarkan proyeksi laba rugi dan arus kas seperti terlihat diatas, untuk usaha penggemukan dan pembibitan sapi serta usaha penggemukan sapi selama kurun waktu lima tahun rencana (2012-2016) dengan tingkat suku bunga $12 \%$ per tahun diperoleh IRR, NPV, 
Tabel 1. Proyeksi laba rugi pembibitan dan penggemukan Sapi Tebu PG. Jatitujuh (Rp)

\begin{tabular}{|c|c|c|c|c|c|c|}
\hline \multirow{2}{*}{ No } & \multirow{2}{*}{ Uraian } & \multicolumn{5}{|c|}{ Tahun } \\
\hline & & 2012 & 2013 & 2014 & 2015 & 2016 \\
\hline & Pendapatan & & & & & \\
\hline 1 & Penjualan sapi bakalan & 163800000000 & 180180000000 & 168022354500 & 112442680350 & 61034083110 \\
\hline 2 & Penjualan sapi jantan umur 2 tahun & - & - & - & - & 4673269941 \\
\hline 3 & Penjualan sapi betina umur 2 tahun & - & - & - & - & 3012019725 \\
\hline \multirow[t]{3}{*}{4} & Penjualan kotoran sapi & 2400000000 & 2640000000 & 2904090750 & 3194000700 & 3513949808 \\
\hline & Jumlah pendapatan & 166200000000 & 182820000000 & 170926445250 & 115636681050 & 72233322584 \\
\hline & Pengeluaran & & & & & \\
\hline 1 & Biaya invenstasi & 23379936505 & 22245049601 & - & - & - \\
\hline 2 & Biaya operasional & 129870000000 & 142857000000 & 159550722338 & 134169310041 & 85188012196 \\
\hline 3 & Penyusutan peralatan & 62300000 & 62300000 & 64300000 & 64300000 & 64300000 \\
\hline \multirow[t]{3}{*}{4} & Penyusutan bangunan & 610000000 & 874000000 & 874000000 & 874000000 & 874000000 \\
\hline & Jumlah pengeluaran & 153922236505 & 166038349601 & 160489022338 & 135107610041 & 86126312196 \\
\hline & Laba/Rugi & 12277763495 & 16781650399 & 10437422912 & (19470928991) & (13892989612) \\
\hline
\end{tabular}

Sumber : Hasil analisis, tahun 2012

Tabel 2. Proyeksi laba rugi penggemukan Sapi Tebu PG. Jatitujuh (Rp)

\begin{tabular}{|c|c|c|c|c|c|c|}
\hline \multirow{2}{*}{ No } & \multirow{2}{*}{ Uraian } & \multicolumn{5}{|c|}{ Tahun } \\
\hline & & 2012 & 2013 & 2014 & 2015 & 2016 \\
\hline \multirow{5}{*}{$\begin{array}{l}1 \\
2\end{array}$} & Pendapatan & & & & & \\
\hline & Penjualan sapi bakalan & 163800000000 & 180180000000 & 198198000000 & 218017800000 & 239819580000 \\
\hline & Penjualan kotoran sapi & 2400000000 & 2640000000 & 2904000000 & 3194400000 & 3513840000 \\
\hline & Jumlah pendapatan & 166200000000 & 182820000000 & 201102000000 & 221212200000 & 243333420000 \\
\hline & Pengeluaran & & & & & \\
\hline 1 & Biaya investasi & 23445936505 & 19677649601 & - & - & - \\
\hline 2 & Biaya operasional & 129870000000 & 142857000000 & 178802150561 & 216333618619 & 237985662397 \\
\hline 3 & Penyusutan peralatan & 62300000 & 62300000 & 62300000 & 62300000 & 62300000 \\
\hline \multirow[t]{3}{*}{4} & Penyusutan Bangunan & 610000000 & 610000000 & 610000000 & 610000000 & 610000000 \\
\hline & Jumlah pengeluaran & 153988236505 & 163206949601 & 179474450561 & 217005918619 & 238657962397 \\
\hline & Laba/Rugi & 12211763495 & 19613050399 & 21627549439 & 4206281381 & 4675457603 \\
\hline
\end{tabular}

Tabel 3. Indikator kelayakan finansial Sapi Tebu (lima tahunan)

\begin{tabular}{clcc}
\hline No & \multicolumn{1}{c}{ Indikator } & Pembibitan (Sapi Tebu) & Penggemukan (Sapi Tebu) \\
\hline 1 & Suku Bunga & $12 \%$ & $12 \%$ \\
2 & IRR & $-93,40 \%$ & $18,92 \%$ \\
3 & NPV & Rp. $(27.651 .279 .034)$ & Rp5.856.142.377 \\
4 & BCR & 0,39 & 1,14 \\
5 & BEP & 13.647 ekor & 27.477 ekor \\
6 & PP & 3,19 tahun & 2,45 tahun \\
\hline
\end{tabular}


Net $\mathrm{B} / \mathrm{C}$ ratio, BEP dan PP seperti terlihat pada Tabel 3.

Hasil analisis kelayakan finansial (Tabel 3) untuk program pembibitan diketahui bahwa nilai IRR di bawah suku bunga yang di syaratkan, Hal ini menunjukkan bahwa pada akhir tahun rencana tingkat pengembalian investasi lebih rendah dari suku bunga yang disyaratkan pada awal tahun rencana.

Sedangkan Net Present Value (NPV) menunjukkan nilai negatif, hal ini menunjukkan bahwa nilai rupiah investasi pada akhir tahun rencana menurun. Sedangkan untuk program penggemukkan nilai IRR di atas suku bunga yang di syaratkan.

Hal ini menunjukkan bahwa pada akhir tahun rencana tingkat pengembalian investasi masih lebih tinggi dari suku bunga yang disyaratkan pada awal tahun rencana. NPV menunjukkan nilai positif, hal ini menunjukkan bahwa nilai rupiah investasi pada akhir tahun rencana masih sangat bernilai. Semakin tinggi nilai IRR maka usaha tersebut semakin berpeluang untuk menciptakan keuntungan.

Tabel 3 memperlihatkan nilai $\mathrm{BCR}>1$ pada usaha penggemukkan sapi namun $\mathrm{BCR}<1$ pada usaha pembibitan. Hal ini berarti bahwa usaha integrasi sapi tebu pada Perkebunan Tebu dan Pabrik gula PG Jatitujuh di Kabupaten Majalengka layak dikembangkan untuk program penggemukkan namun belum layak untuk program pembibitan (budidaya). Untuk program penggemukan dalam jangka 5 tahun usaha ini cukup efisien namun untuk progam pembibitan kurang efisien. Hal ini sesuai dengan pernyataan Kadariah (1987) bahwa BCR merupakan salah satu komponen untuk menilai tingkat efisiensi suatu usaha. Muller (1986) menyatakan tingkat keberhasilan suatu usaha peternakan dapat dilihat dari tingkat pendapatan BCR. Semakin besar nilai BCR maka semakin efisien modal usaha yang digunakan atau sebaliknya (Mubyarto, 1977).

Analisis Break Even Point (BEP) dihitung bertujuan untuk mengetahui titik impas (kondisi dimana perusahaan tidak untung dan juga tidak rugi), sehingga pada kondisi ini pendapatan yang diperoleh sama dengan modal usaha yang dikeluarkan (Riyanto,
1995). Dari hasil analisis (Tabel 3) pada program pembibitan diperoleh BEP sebesar 13.647 ekor dan 27.477 ekor pada program penggemukan. Ini berarti untuk kembalinya modal awal dimana peternak tidak mengalami keuntungan atau kerugian adalah setelah peternak memelihara 13.647 ekor sapi untuk dibudidayakan atau 27.477 ekor sapi untuk digemukkan, dengan kata lain investasi akan pulang pokok apabila ternak yang dijual sebanyak 27.477 ekor.

Analisa sensitifitas usaha pembibitan dan penggemukan sapi tebu dan sapi sawit dalam kurun waktu sepuluh tahun dapat dilihat pada Tabel 4.

Tabel 4. Analisa sensitifitas pembibitan dan penggemukan Sapi Tebu (selama sepuluh tahun)

\begin{tabular}{clc}
\hline No & \multicolumn{1}{c}{ Indikator } & $\begin{array}{c}\text { PG. Jatitujuh (Sapi } \\
\text { Tebu) }\end{array}$ \\
\hline 1 & Suku Bunga & $12 \%$ \\
2 & Populasi Sapi & $4.000 \mathrm{ST}$ \\
3 & Induk Sapi & 2.136 Ekor \\
4 & IRR & $13,97 \%$ \\
5 & NPV & Rp. 4.136.510.427 \\
6 & BCR & 1,09 \\
7 & BEP & 5.942 ekor \\
8 & PP & 7,99 Tahun \\
\hline
\end{tabular}

Dari analisa sensitifitas diatas terlihat bahwa usaha pembibitan dan penggemukan sapi memiliki IRR, NPV dan BCR positif atau layak untuk dilaksanakan dalam kurun waktu sepuluh tahun rencana. Analisa sensitifitas usaha penggemukan Sapi Tebu terhadap beberapa variabel penting dapat dilihat pada Tabel 5.

\section{Aspek Sosial dan Ekonomi}

Keberadaan peternakan sapi di Kabupaten Majalengka tidak terlepas dari keadaan sosial ekonomi masyarakat yang ada di sekitarnya. Dengan jumlah penduduk dan tingkat kepadatan yang cukup tinggi, Kabupaten majalengka memiliki masalah dalam menampung angkatan kerja yang terdapat di wilayah tersebut. Munculnya pengangguran dan tingkat pendidikan serta tingkat kesejahteraan yang rendah setidaknya dapat 
Tabel 5. Analisa sensitifitas penggemukan Sapi Tebu PG. Jatitujuh

\begin{tabular}{clcccc}
\hline \multirow{2}{*}{ No } & \multicolumn{1}{c}{ Uraian } & $\%$ & IRR & NPV & BCR \\
& & & $18,92 \%$ & $\mathrm{Rp} 5.856 .142 .377$ & 1,14 \\
\hline 1 & Penyusutan Ternak Waktu Pembelian & 10 & 7,36 & $\mathrm{Rp}(3.494 .107 .244)$ & 0,92 \\
2 & Tingkat Kematian Sapi Bakalan & 5 & 7,36 & $\mathrm{Rp}(3.494 .107 .244)$ & 0,92 \\
& Meningkat & 5 & 7,87 & $\mathrm{Rp}(3.143 .808 .362)$ & 0,93 \\
3 & Pertumbuhan Berat Sapi Menurun & 50 & 15,75 & $\mathrm{Rp} 3.086 .926 .765$ & 1,07 \\
4 & Harga Jual Kotoran Sapi Menurun & 5 & 9,50 & $\mathrm{Rp}(1.821 .142 .267)$ & 0,96 \\
5 & Biaya Operasional Naik & & &
\end{tabular}

Sumber : Hasil analisis, tahun 2012

diatasi dengan membuka lapangan pekerjaan baru.

\section{KESIMPULAN}

1. Usaha pembibitan dan penggemukan sapi memiliki prospek pasar yang masih berkembang. Indikasi tersebut dapat dilihat dari volume perdagangan sapi selama ini masih menunjukkan peningkatan, dan munculnya pelaku pelaku usaha baru pada usaha ternak sapi.

2. Penggunaan bahan pakan ternak di PD. Jatitujuh adalah pucuk tebu, sogolan, kletekan, bagas, blotong ditambah dengan bahan pakan lainnya.

3. Untuk sapi bakalan dan sapi induk dipilih jenis sapi Brahman Cross, Peranakan Simental, Peranakan Limousine dan Peranakan Ongole (PO).

4. Dari sisi aspek teknis dan produksi, usaha pembibitan sapi dimulai pada tahun ketiga.

5. Ditinjau dari aspek keuangan, usaha pembibitan sapi belum layak untuk dilaksanakan dalam kurun waktu lima tahun rencana dengan tingkat suku bunga $12 \%$ per tahun, akan tetapi untuk usaha penggemukan sapi dalam kurun waktu lima tahun rencana dengan tingkat suku bunga $12 \%$ layak untuk dilaksanakan.

6. Usaha penggemukan dan pembibitan sapi dalam kurun waktu sepuluh tahun rencana dengan tingkat suku bunga 12\% layak untuk dilaksanakan. Hasil analisis sensitifitas terhadap kenaikan angka penyusutan sapi dalam pengangkutan pada waktu

7. Usaha pembibitan dan penggemukan sapi memiliki prospek pasar yang masih berkembang. Indikasi tersebut dapat dilihat dari volume perdagangan sapi selama ini masih menunjukkan peningkatan, dan munculnya pelaku pelaku usaha baru pada usaha ternak sapi.

8. Penggunaan bahan pakan ternak di PD. Jatitujuh adalah pucuk tebu, sogolan, kletekan, bagas, blotong ditambah dengan bahan pakan lainnya.

9. Untuk sapi bakalan dan sapi induk dipilih jenis sapi Brahman Cross, Peranakan Simental, Peranakan Limousine dan Peranakan Ongole (PO).

10. Dari sisi aspek teknis dan produksi, usaha pembibitan sapi dimulai pada tahun ketiga.

11. Ditinjau dari aspek keuangan, usaha pembibitan sapi belum layak untuk dilaksanakan dalam kurun waktu lima tahun rencana dengan tingkat suku bunga $12 \%$ per tahun, akan tetapi untuk usaha penggemukan sapi dalam kurun waktu lima tahun rencana dengan tingkat suku bunga $12 \%$ layak untuk dilaksanakan. Usaha penggemukan dan pembibitan sapi dalam kurun waktu sepuluh tahun rencana dengan tingkat suku bunga 12\% layak untuk dilaksanakan. Hasil analisis sensitifitas terhadap kenaikan angka penyusutan sapi dalam pengangkutan pada waktu pembelian, kenaikan angka kematian sapi bakalan, terjadinya penurunan angka pertumbuhan berat badan sapi dan kenaikan biaya operasional menyebabkan usaha penggemukan sapi tidak layak untuk dilaksanakan.

12. Analisa aspek sosial, ekonomi, dan lingkungan juga menunjukkan bahwa usaha 
pembibitan dan penggemukan sapi layak dikembangkan, karena selain menciptakan lapangan kerja di pedesaan juga tidak merusak lingkungan.

13. Usaha pembibitan dan penggemukan sapi mempunyai dampak ekonomi bagi peternak dan masyarakat sekitar.

\section{UCAPAN TERIMAKASIH}

Kami mengucapkan terima kasih kepada PT. Rajawali Nusantara Indonesia, cabang Jatitujuh Kabupaten Majalengka, pemerintah daerah kabupaten Majalengka, Dinas Peternakan dan Pertanian Kabupaten Majalengka dan semua pihak yang telah membantu terlaksananya penelitian ini.

\section{DAFTAR PUSTAKA}

Badan Pusat Statistik. 2013. Konsumsi dan pengeluaran. Badan Pusat Statistik Republik Indonesia, Jakarta.

Kadariah. 1987. Pengantar evaluasi proyek program perencanaan nasional. Lembaga Penelitian Ekonomi Dan Masyarakat. Penerbit FE UI.

Mubyarto. 1977. Pengantar Ekonomi Pertanian. Lembaga Penelitian Dan Pendidikan Sosial Ekonomi.

Muler. 1986. Farm Manajemen Conseling Manager And Rural Appalsers.

Riyanto, B. Dasar-Dasar Pembelanjaan Perusahaan. Yayasan Gadjah Mada, Yogyakarta.

Umar, H. 2001, Studi Kelayakan Bisnis, Gramedia Pustaka Utama, Jakarta. 